

\section{Políticas de la mirada, memorialización y musealización. Aportes para un estado de la cuestión}

\section{Artículo de revisión}

Recibido: 21 de junio de 2021

Aprobado: 14 de agosto del 2021

\section{Sonia Vargas Martínez}

Universidad Nacional de Colombia, Sede Bogotá, Colombia

sopvargasma@unal.edu.co

Vargas Martínez, Sonia (2022). Políticas de la mirada, memorialización y musealización. Aportes para un estado de la cuestión. Estudios Artísticos: revista de investigación creadora, 8(12) pp. 92-111. DOI https://doi.org/10.14483/25009311.18766

Imagen 1. Mantos de Mampujan, realizados por mujeres tejedoras de Mampujan. Sala Memoria y Nación, Museo Nacional de Colombia. Archivo personal.

\section{(c) (i)}

https://creativecommons.org/licenses/by/4.0/deed.es

\section{Resumen}

Este artículo de revisión tiene como objetivo trazar un estado actual del conocimiento alrededor de la musealización de la memoria, su relación con la imagen y los afectos, mediante el estudio amplio de antecedentes y referentes que dará cuenta de sus principales enfoques y sus posibles vacíos, algunos de los cuales pretenderé responder con mi propio proyecto de investigación-creación aquí expuesto. Para este fin he ubicado el espacio abierto por los debates de cinco ejes problémicos, éstos son: 1.) Giro memorialista, 2.) Musealización, 3.) Régimen visual y colonialidad, 4.) Imagen y memoria, 5.) subjetivación y afectos. Parto del reconocimiento que más que definiciones definitivas, presento definiciones operativas, provisionales e inseguras (García Canclini, 2001) que nos permitan seguir investigando. Muchos de los trabajos aquí expuestos transitan por más de un eje, dejando ver su carácter poroso. Este recorrido dará cuenta de los puntos de encuentros de las investigaciones y aportará a la construcción de nuevas apuestas.

\section{Palabras clave}

Afectos; imagen y memoria; musealización; régimen visual; colonialidad

\section{Politics of the gaze, memorialization and musealization. Contributions to a state of the matter}

\footnotetext{
Abstract

This review article aims to trace the current state of knowledge around the musealization of memory, and its relationship with the image and affections, through the extensive study of antecedents and references that will account for its main approaches and its possible gaps, some of which I will try
} 
to answer with my own research-creation project, presented here. For this purpose, I have located the main debates around five problematic axes: 1.) Memorialist turn, 2.) Musealization, 3.) Visual regime and coloniality, 4.) Image and memory, 5.) Subjectivation and affects. I start from the recognition that, more than definitive statements, I present operative, provisional and insecure definitions (García Canclini, 2001) that allow us to continue investigating. Many of the works exhibited here pass through more than one axis, revealing their porous character. This tour will give an account of the meeting points of different research projects and will contribute to the construction of new proposals.

\section{Keywords}

Affections; image and memory; musealization; visual regime; coloniality

\section{Politique du regard, mémorialisation et muséalisation. Contributions à un état de la question}

\section{Résumé}

Cet article de synthèse vise à retracer l'état actuel des connaissances autour de la muséalisation de la mémoire, et son rapport à l'image et aux affections, à travers l'étude approfondie d'antécédents et de références qui rendront compte de ses principales approches et de ses éventuelles lacunes, dont certaines je tenterai d'y répondre avec mon propre projet de recherche-création, présenté ici. Pour cela, i'ai localisé les principaux débats autour de cinq axes problématiques : 1.) Tourné mémorialiste, 2.) Muséalisation, 3.) Régime visuel et colonialité, 4.) Image et mémoire, 5.) Subjectivation et affects. Je pars de la reconnaissance que, plus que des déclarations définitives, je présente des définitions opérationnelles, provisoires et précaires (García Canclini, 2001) qui nous permettent de continuer à enquêter. Beaucoup d'œuvres exposées ici traversent plus d'un axe, révélant leur caractère poreux. Cette visite rendra compte des points de rencontre de différents projets de recherche et contribuera à la construction de nouvelles propositions.

\section{Mots clés}

Affections ; image et mémoire ; muséalisation ; régime visuel ; colonialité

\section{Políticas do olhar, memorialização e musealização. Contribuições para um estado da questão}

\section{Resumo}

Este artigo de revisão tem como objeto traçar um estado atual do conhecimento ao redor da musealização da memória, sua relação com a imagem e os afetos, mediante o estudo amplo de antecedentes e referências que darão conta de seus principais enfoques e suas possíveis lacunas, algumas das quais pretenderei responder com meu próprio projeto de investigação- criação aqui exposto. Para este fim, localizei o espaço aberto pelos debates de cinco eixos problemáticos, que são: 1.) Giro memorialista, 2.) Musealização, 3.) Regime visual e colonialidade, 4.) Imagem e memória, 5.) subjetivação e afetos. Parto do reconhecimento de que, mas do que definições definitivas, apresento definições operativas, provisórias e inseguras (García Canclini, 2001) que nos permitam seguir investigando. Muitos dos trabalhos aqui expostos transitam por mais de um eixo, deixando ver seu caráter poroso. Este percurso dará conta dos pontos de encontros das investigações e contribuirá para a construção de novas apostas.

\section{Palavras Chave}

Afetos; imagem e memória; musealização; regime visual; colonialidade

\section{Ruranakuskata kawaspa, iachaikuii ruraikunata wakachidiru, iachaska iadachispa apachii}

\section{Maillallachiska}

Kaipi Munanaku iachanga allilla ruraskachu ka, pai munaku ñugpamandata kausaita pangapi kilkaspa parlanga kunaura nispa suma ruraspa churangapa tukuikuna kawachu. lachaikuku Achka chasa kawaku Tukui churaskachka u charrach. Pisiku mailla mailla ainisami pichka tapuchii sug kami suti mullurii iuiarispa, kai suma ruraita churangapa kinsa allilla kawai, chusku kawai iuiarii pichka kausai ruraikuna. Kallarikuni iuiachispa allilla kawangapa churaspa pangapi nispa munaura anchuchingapa ( García Canclini 2001) llukanchi chara tapuchinga imapas kai ruraikuna tiankunami churaska rurespa 


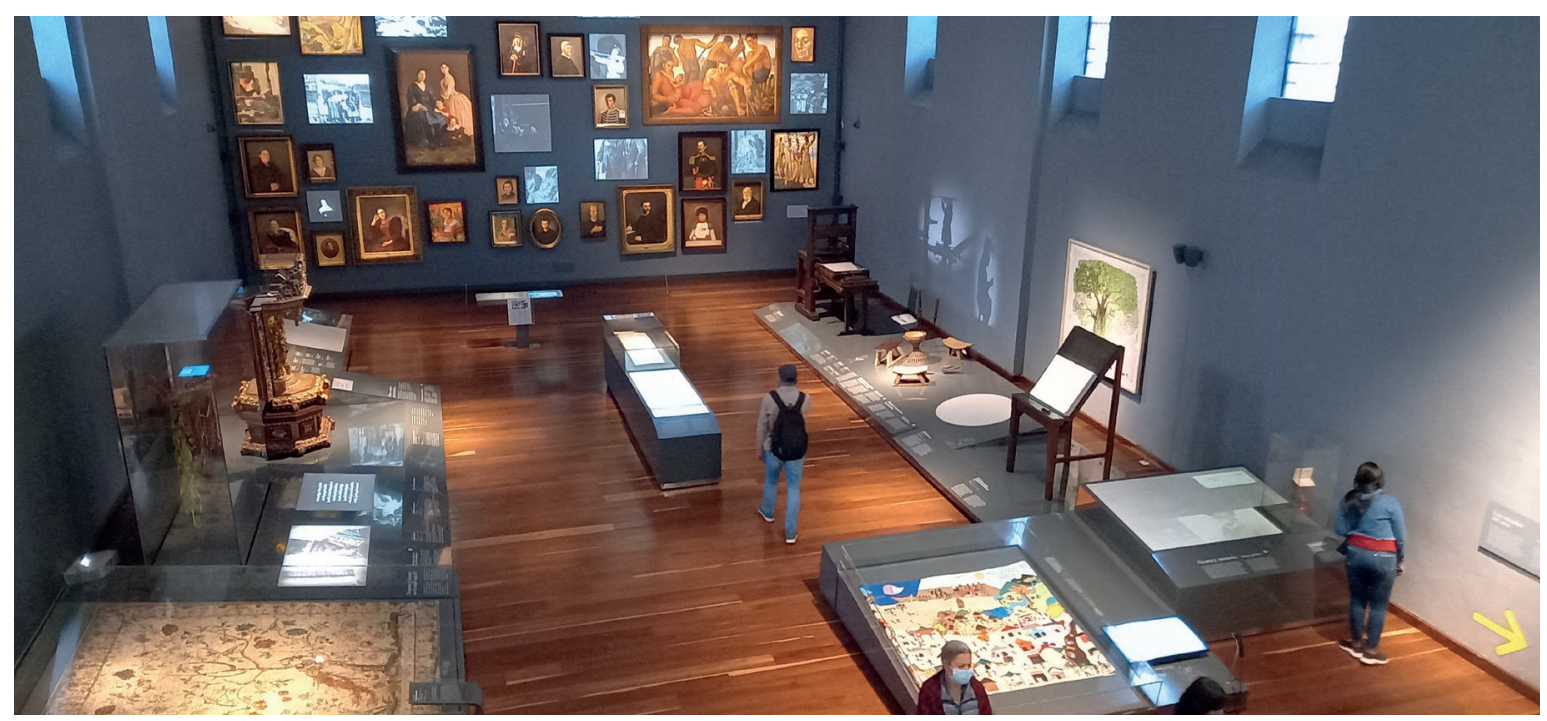

Imagen 2. Sala Memoria y Nación, Museo Nacional de Colombia. Sala Memoria y Nación, Museo Nacional de Colombia. Archivo personal.

Achka tapuchispa aidachingamika sug kati ruraskakunata ñugpama katichingapa.

\section{Rimangapa Ministidukuna}

Rurai ruranakuska; kai kawachii ruraskata iuiarii; sumaglla ruraskata churai; kawachita apachii ñugpamandakunata

\section{Introducción}

Tras la firma de los Acuerdos de Paz en Colombia en 2016, entre el Gobierno de Colombia y las Fuerzas Armadas Revolucionarias de Colombia, Ejército del Pueblo (FARC-EP), son potenciadas y ampliadas distintas prácticas de memorialización o formas de erigir recordatorios públicos de eventos del pasado, como estrategia para la visibilización y recuperación de la memoria del conflicto armado. Como parte de estas prácticas, que ya venían de tiempo atrás, destacan los procesos de reparación simbólica a las víctimas, algunos de ellos concretados en actos públicos de pronunciamientos de perdón por parte de sus victimarios, que buscan el reconocimiento de los hechos, así como actos de reconciliación entre las partes como sinónimo de la paz. En cumplimiento de sentencias judiciales, se han encomendado esculturas y monumentos para el reconocimiento de la dignidad de las personas victimizadas, mediante los cuales se busca atender las dimensiones irreparables causadas en el marco del conflicto armado. ${ }^{1}$ Se han realizado varias exposiciones en el Centro Nacional de Memoria Histórica-CNMH, así como homenajes y conmemoraciones a las víctimas. Desde la aprobación de la Ley de víctimas, en 2011, cada 9 de abril se conmemora el Día Nacional de la Memoria y la Solidaridad con las Víctimas del conflicto armado. Por su parte, las comunidades afectadas, como iniciativa propia, han realizado prácticas de duelo y resiliencia, como forma de superación del trauma y como vía para la construcción de memorias alternativas.

A la par de este auge se han realizado varias exhibiciones relacionadas con la representación del conflicto armado, emprendidas desde el campo del arte y llevadas a cabo en espacios como museos, salas, universidades, bibliotecas, como forma de dialogar con el pasado, donde se introducen

\footnotetext{
1 Monumento a los Caídos, Bogotá, 2013. Monumento alegórico a la vida en el parque principal de Yarumal, Antioquia, 2014. Lugar de la Memoria, Villavicencio, Meta, 2014; por citar solo algunos ejemplos de sentencias judiciales.
} 
representaciones del conflicto armado y experiencias de las víctimas, mediadas por lenguajes plásticos. Para ilustrar, menciono algunas exhibiciones ampliamente reconocidas; La guerra que no hemos visto, realizada por Juan Manuel Echavarría y la Fundación Puntos de Encuentro, en el Museo de Arte Moderno de Bogotá -MAMBO en 2009; Río Abajo, realizada por Érika Diettes en el Museo de Arte de la Universidad Nacional de Colombia en 2008; Memorias Plurales del conflicto, realizado por la Embajada de Francia y el CNMH en 2019, todas realizadas en Bogotá.

Con el llamado boom de la memoria o "efecto de memoria", que surge en la década de los años 80 a nivel internacional, se activan numerosas exhibiciones, lo cual ha contribuido a la emergencia de lo que se ha llamado el Giro memorialista; una necesidad (y hasta obsesión) cultural global y nacional por la memoria, por la consignación o almacenamiento de la memoria cultural (Hyussen, 2002; Guash, 2014).

En América Latina, la Cultura de la Memoria emerge como respuesta tras los procesos dictatoriales del Cono Sur, poniendo en perspectiva las violaciones de los derechos humanos, la justicia y la responsabilidad colectiva. La memoria se convierte en un régimen global de producción del pasado (Jelin, 2011). En contextos de dictaduras donde hubo un empeño por borrar todo registro de su actuación, el miedo al olvido y la necesidad de recordar hicieron de las exhibiciones un imperativo.

Con la emergencia de las exhibiciones surgen prácticas de musealización, esto es, la multiplicación de objetos insertos en espacios museales, los cuales adquieren unas determinadas cualidades simbólicas: la musealización separa a los objetos de sus contextos físicos, transforma su función originaria, le otorga un específico valor inmaterial y los enmarca en lenguajes comprensibles para la audiencia que participa de los espacios exhibitivos. A su vez, la audiencia concede valoraciones e interpretaciones a estos objetos, en relación a las cualidades y valores asignados en el proceso de musealización, en este proceso entra en juego su subjetividad.

En Colombia, sin embargo, la atención se ha visto mayormente centrada en el análisis de obras e imágenes realizadas por artistas que representan o interpelan la violencia, desde disciplinas como la Historia del arte, y en algunos postulados propuestos por la psicología y el apoyo psicosocial, los cuales otorgan un marco de legibilidad particular al arte y la cultura; situación evidente en la reiteración de nociones como resiliencia, superación del trauma, sanación, entre otras. Ambas aproximaciones se han entendido tanto, al punto de llegar a ser casi la lengua oficial de los estudios de la memoria en el contexto colombiano.

Como contravía a estas actuales corrientes dominantes, me propuse realizar una investigación-creación ${ }^{2}$ desde la cual fuera posible plantear otras preguntas y otros abordajes al estudio acerca de la memoria del conflicto armado en Colombia, que pusiera como centro el creciente auge de las exhibiciones realizadas en el país, su impacto visual y prestigio moral, como corolario del dolor que éstas representan y presentan.

\section{Investigación creación sobre la musealización de la memoria}

Las inquietudes por la musealización de la memoria del conflicto armado colombiano surgieron de motivaciones personales vinculados con mi historia familiar cargada de silencios y olvidos intencionados provocados por el conflicto armado, así como por experiencias de orden reflexivo y crítico como investigadora y docente interesada por la visualidad y la memoria. Desde estos escenarios, me interrogo por ¿Qué se hace con el pasado recuperado cuando éste es llevado a las salas expositivas? Y en tanto espectadoras y espectadores ¿Cómo nos relacionamos con las simbolizaciones del pasado? y ¿Qué hacemos con el dolor?

En todo esto, mi lugar de provocación es la academia, pese a que se ha estabilizado una dicotomía entre teoría y práctica, según la cual, la academia opera como el "adentro" de la teoría, mientras que la acción política acontece en el "afuera" que

\footnotetext{
2 La investigación se titula tentativamente: Políticas de la mirada en procesos de musealización de la memoria del conflicto armado en Colombia (inició en 2019 y se encuentra en proceso de realización) realizada en el marco del Doctorado de Estudios Artísticos de la Universidad Distrital Francisco José de Caldas.
} 
constituye la práctica social. En contraposición a esta perspectiva, asumo que la academia y sus labores investigativas son también territorio de intervención política, por ser un "campo de fuerzas atravesado por relaciones de poder y resistencia entre prácticas, discursos, identidades, subjetividades, cuerpos e instituciones" (Richard, 2018, p. 179).

La intención es interrogar los modos de producción de la memoria del conflicto armado colombiano desde la visualidad (campo expandido de las imágenes y los actos del ver) en el caso específico de tres exhibiciones: El testigo, memorias del conflicto armado en el lente y la voz de Jesús Abad Colorado, Fragmentos de Doris Salcedo, y la sala permanente Memoria y Nación del Museo Nacional de Colombia. ${ }^{3}$ Todas estas prácticas de musealización traen consigo situaciones que me interesa poner a consideración y problematizar. Estas son: a.) los marcos de sentido que emergen en los espacios exhibitivos, b.) Las visualidades que construyen las formas de presentar-mostrar, y c.) La subjetivación mediante la construcción de una mirada moral en los y las espectadores. Es importante señalar que, al parecer, estas tres instancias

\footnotetext{
3 La muestra antológica El testigo, memorias del conflicto armado en el lente y la voz de Jesús Abad Colorado, ubicada en el Claustro de San Agustín, que exhibe más de 500 fotografías de víctimas del conflicto armado realizadas por el fotoperiodista en los últimos 30 años. Aquí, busco analizar la aceptación de la audiencia y la construcción de consensos sociales, problematizar las relaciones coloniales entre el ver-conocer. Me inquieta cómo su narración visual y oral conduce la visualidad y la mirada, y cómo gestan la triada: imagen, imaginario y memoria. Fragmentos de Doris Salcedo, fue concebido como lugar de la memoria, donde habita un contra monumento que consiste en una superficie de metal fundido de 37 toneladas de armas entregadas por las FARC-EP, realizado en colaboración con mujeres víctimas de violencia sexual en el conflicto armado. Me pregunto por la mediación de las mujeres que participaron en este proyecto, así como por los discursos sobre víctimas y victimarios y otros sentidos que produce dicho contramonumento. La sala permanente Memoria y Nación del Museo Nacional de Colombia, donde se encuentran algunos trabajos textiles realizados por las mujeres tejedoras de Mampuján en los que representan distintas escenas del conflicto. Allí, me pregunto por las formas generizadas de construcción de memoria, por la entrada de los trabajos textiles a los espacios museales que se ha dado en relación al canon dominante y por la relación entre visualidad y relato de nación.
}

no operan por separado y que, al contrario, son mutuamente constitutivas.

En este sentido, la entrada por las exhibiciones permitirá avanzar hacia su multidimensionalidad como práctica cultural que construye formas del mostrar y del ver; y las interacciones entre lo visual y los aparatos, las instituciones, los discursos, discursos visuales, las representaciones, las corporalidades, la espacialidad; así como los usos de las imágenes, los imaginarios, miradas, actos del ver, subjetividad y el poder. A través de ellas me interesa explorar y producir conocimiento sensible en torno de las instituciones, los regímenes visuales, el lugar de la audiencia, entre otros, aportando al entendimiento de cómo se normalizan determinadas construcciones de lo social vía la visualidad, desde intervenciones de apuestas críticas de los estudios artísticos, en diálogos interepistémicos entre estudios visuales y enfoques feministas y decoloniales. Los estudios visuales en mi proyecto marcan un acento por las políticas de la mirada y los regímenes visuales de representación. La producción de sentido y las agendas que atraviesan sus formas de circulación y consumo. La pregunta de cómo se produce lo visto, así como las formas de visibilización y ocultamiento. "No solo como reflexión especular sino como distorsión representacional" (Cabrera, 2006). Así mismo, asumo el feminismo como una perspectiva, no necesariamente a las mujeres como objeto de estudio, que permite el entendimiento del género como una relación y una forma de dominación articulada a otros órdenes de poder como la clase social, la raza y la etnicidad.

Me pregunto específicamente por las maneras como estas prácticas de musealización afectan los objetos -de la memoria- al ser exhibidos (ya sean fotografías, tejidos, entre otros); ¿cómo se imbrican las clasificaciones de género, raza, etnia?, ¿cómo afectan a espectadoras y espectadores?; ¿qué tipos de relatos colectivos hacen posibles estas prácticas? En términos generales, indago la posible existencia de una política estatal colonial de administración de la memoria y el olvido en Colombia, que tiene un régimen de producción de lo sensible, determinante para el funcionamiento de las emociones y su relación con la memoria.

Para ello, propongo las prácticas de musealización de la memoria como tecnologías políticas y 
agendas de control afectivo de regulación y control sobre la representación y modos de exhibir el conflicto armado y busco indagar los dispositivos coloniales que intervienen en la producción de la memoria y las emociones, las cuales impactan la subjetividad.

\section{Armar un estado de la cuestión}

El objetivo de este artículo de revisión es dar cuenta del estado actual del conocimiento alrededor de procesos de memorialización y musealización de la memoria, mediante el estudio amplio de antecedentes y referentes nacionales e internacionales que dará cuenta de los principales enfoques y sus posibles vacíos, algunos de los cuales pretenderé responder con mi proyecto de investigación-creación. Para fines de esta investigación y de este artículo he ubicado el espacio abierto por los debates de cinco ejes problémicos, éstos son: 1.) Giro memorialista, 2.) Musealización, 3.) Régimen visual y colonialidad, 4.) Imagen y memoria, 5.) subjetivación y afectos. Parto del reconocimiento que más que definiciones definitivas, como señala Néstor García Canclini, presento definiciones operativas, provisionales e inseguras (García Canclini, 2001) que nos permita seguir investigando. Muchos de los trabajos aquí expuestos transitan por más de un eje, con esto quiero señalar el carácter poroso de éstas, que, en últimas, es la intención de esta investigación en proceso. Este recorrido o mapeo dará cuenta de los puntos de encuentros, las distancias y las resonancias de distintas investigaciones y aportará a la construcción de nuevas apuestas o enfoques emergentes.

Estos ejes problémicos se encuentran enmarcados y estrechamente relacionados con la noción de Colonialidad cultural propuesta por Aníbal Quijano (2000), (o más precisamente como colonialidad del imaginario, una noción decolonial amplia e inclusiva de los patrones de conocimiento y sus distintos modos de expresión que va más allá de la concepción lacaniana de lo imaginario y la concepción de Gruzinsky de guerra de las imágenes) como el despojo de saberes y los imaginarios de los pueblos colonizados que provocó que las creencias, patrones y modos de significación de los vencidos fueran reemplazados por una herencia intelectual, estética y visual foránea, cuyas formas de percepción y construcción de conocimiento se volvieron hegemónicos y determinantes de las formas del sentir y del ser, propias de unas relaciones de poder que en última instancia encuentra su lugar de inscripción en la corporeidad (Quijano, 2000). Así, estos ejes se insertan, dialogan o son herederas de dicha colonialidad cultural, la cual participa de la administración de la memoria y el olvido en Colombia.

\section{Giro Memorialista}

Ha sido entendido como un fenómeno global que tiene como propósito almacenar la memoria cultural. Andreas Hyussen, ha sido uno de los principales pensadores en reflexionar de manera crítica sobre este fenómeno y es el principal referente sobre el tema. Huyssen señala que dicho giro es una necesidad y hasta obsesión global por la memoria y por la consignación de la memoria cultural (2002). Desde una perspectiva crítica, Hyussen pone de relieve los usos del Holocausto como tropo universal del trauma histórico que se repite en varios contextos, al punto de convertirse hoy en un movimiento transnacional de discursos sobre la memoria traumática, es decir en un índice. Este autor realiza valiosos planteamientos sobre la globalización de la memoria traumática y pone de relieve los efectos de la mercantilización y la espectacularización de la memoria en procesos exhibitivos, desde dónde la política del recuerdo pasa a ser el de memorias comercializadas y consumidas, incluso "igual que la diversión" y el espectáculo, en tanto se encuentran ancladas en el mercado capitalista (Hyussen, 2002, p. 14). En este marco, la paradoja de la memoria, señalada por Hyussen, radica en cómo a la par de su creciente auge, emerge un creciente auge del olvido, caracterizado por la anestesia, la obnubilación, la falta de voluntad para recordar, la pérdida de la conciencia histórica propias de nuestro tiempo. Ante la globalización y mercantilización de la memoria el autor propone distinguir entre los pasados utilizables y los datos descartables, apelando seguramente con ello al derecho a ciertos olvidos.

Por su parte, autoras como Ana María Guash, desde la historia del arte, pone de relieve el papel del arte actual en el auge de dicho Giro memorialista, advierte que la memoria se ha convertido 
tanto en una preocupación histórica como en un problema artístico y teórico y que este boom de la memoria se caracteriza por el miedo al olvido y la necesidad de recordar, las cuales hacen de las exhibiciones un imperativo (Guash, 2014). Para esta autora el Giro memorialista u obsesión por la memoria deviene como una forma de consignación o almacenamiento (Hypónema), tanto de la memoria individual, pero sobretodo de la colectiva y cultural (Guash, 2014, p. 86.). Esta autora examina el arte y el fenómeno de la globalización, aportando nuevos significados que superen la idea de homogeneización, apelando a lecturas por las implicaciones geopolíticas, culturales y contextuales, incluyendo el debate por lo identitario, la alteridad y la construcción de la otredad, y apelando a debates epistemológicos sobre la interculturalidad (Guash, 2011). Sin embargo, su examen centrado en el arte no considera otras prácticas culturales y se inscribe en la lectura de las relaciones entre artistas, obras y contextos.

En el contexto latinoamericano, el Giro memorialista, ha cobrado actualidad y relevancia, desde los años noventa. Es leído como un fenómeno global "que puede considerarse, característico del mundo actual" (Coro Rubio, 2016, p. 344), relacionado con la producción de la memoria sobre todo traumática, siguiendo a Hyussen, que tiene como objetivo la producción del recuerdo, la superación del pasado y las luchas contra el olvido, en las que tiene lugar el arte; sean éstas recordatorios, memoriales, así como la realización de monumentos, santuarios, museos, o espacios destinados al recuerdo. Todo esto, ha servido incluso para abordar la justicia proponiendo narrativas sobre la verdad. Sus fines políticos son diversos y apuntan a la construcción de nación; de patriotismo y expresión de identidades nacionales, convirtiéndose en soporte de la memoria nacional. (Coro Rubio, 2016, p. 344).

En países como Argentina, con una historia marcada por las dictaduras militares, se ha abordado de manera crítica el Giro memorialista; la emergencia de museos, memoriales, muestras, artefactos dedicados al pasado, así como su consumo y posibles efectos para la construcción no solamente de la nación sino también de la historia (Vezzetti, 2015). Se ha hecho énfasis en el modo en que las sociedades abordan la relación con su pasado y ponen de relieve el deber moral contra las formas de olvido y su encubrimiento (Vezzetti, 2015). Otras investigaciones realizadas en este mismo país, examinan la relación entre memoria y la mass-mediación, como proceso de mnemosemiótica; conformación de archivos en el mundo contemporáneo; de escenarios locales, pero también mundiales y globales, con fines de construcción de memorias públicas, que tiene como fin la actualización de los sentidos (García, 2013). Algunas más actuales, examinan las exposiciones y sus modos de exhibir, cruzando enfoques teóricos de los Estudios visuales aplicados a la museología, con el fin de caracterizar y comparar propuestas museográficas, teniendo en cuenta los límites del sistema del arte (Panozzo-Zenere; Olivari, 2020).

Hay que destacar que estas investigaciones son recientes, lo que da cuenta de la relevancia que ha cobrado el análisis del Giro memorialista en nuestro continente. Varias de ellas son realizadas en el Cono Sur, especialmente Argentina, como resultado de un examen crítico sobre las producciones de la memoria. Sin embargo, investigaciones como estas al parecer no se ocupan del lugar de la mirada, los afectos, ni los procesos de subjetivación que activan las memorializaciones y las exhibiciones.

En Colombia, estamos en proceso de producciones de las memorias, pero más que en el Giro memorialista, la producción académica se centra en temas como la resiliencia y capacidad sanadora del arte (Acosta, 2019) el apoyo psicosocial al dolor y el trauma colectivo (Martínez, 2012), la posibilidad del arte como forma de activar procesos con la gente, las comunidades y las juventudes (Rubiano, 2014; Gutiérrez, 2016, Riaño, 2006), algunas han controvertido la revictimización, realizando valiosos aportes desde análisis críticos de los discursos, entre otros (Bustos, 2019; Roque, 2018; Yepes, 2012). Otras perspectivas críticas han señalado el actual interés académico y extra académico por la memoria como formas de valoración del mundo social, analizando las maneras como los elementos performativos (rituales y conmemoraciones) y narrativos (testimonios), son centrales en el diálogo con el pasado, en contraste con el modelo "sacrificial" de formación de la memoria colombiana; es decir, las formas violentas como la memora se inscribe en el cuerpo (Cabrera, 2006). 


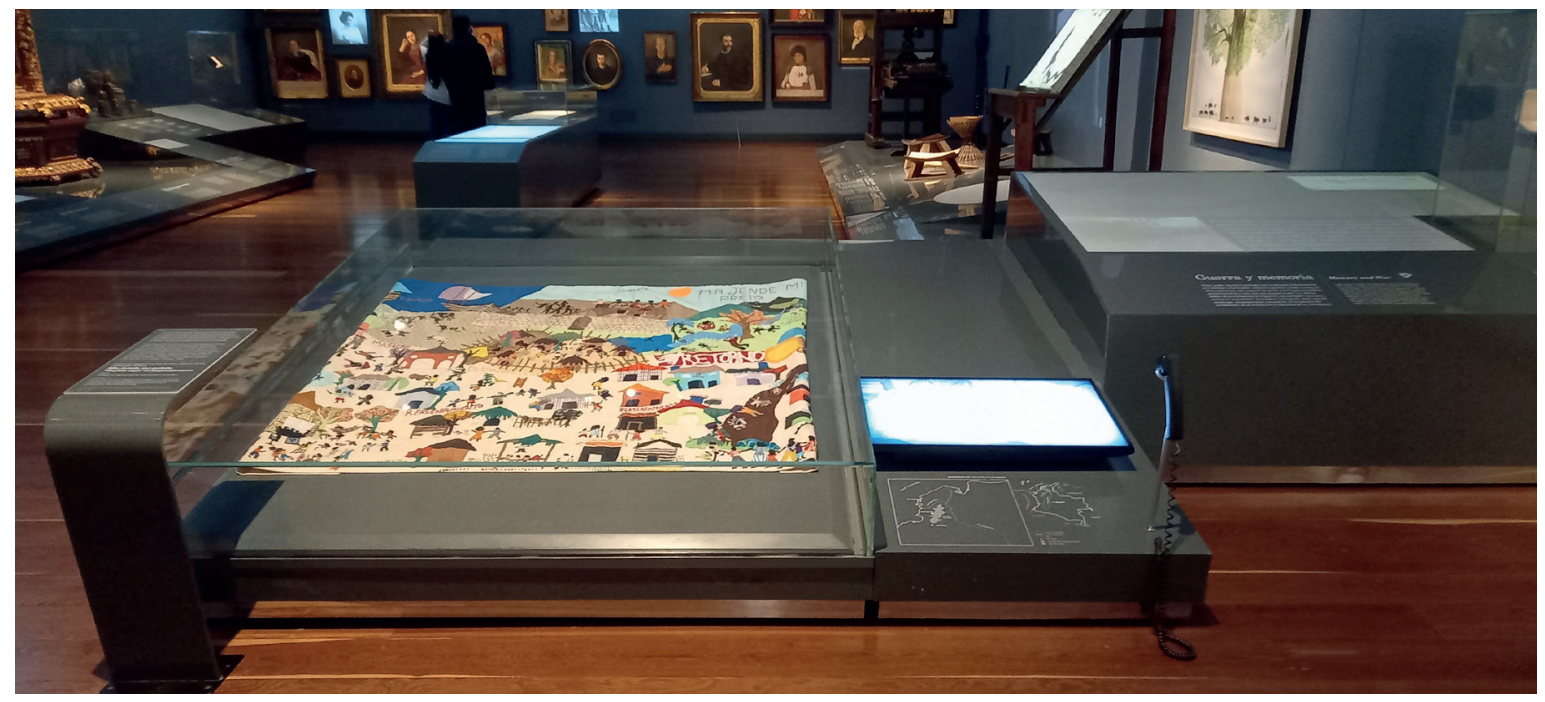

Imagen 3 y 4. Mantos de Mampujan, realizados por mujeres tejedoras de Mampujan. Sala Memoria y Nación, Museo Nacional de Colombia. Archivo personal.

\section{Musealización}

La musealización es un proceso que se da especialmente en el marco de la construcción de ciertas exhibiciones, se encarga de separar los objetos de sus contextos y territorios, de esta manera transforma su función originaria, les otorga un específico valor inmaterial y los enmarca en lenguajes comprensibles para la audiencia que participa de los espacios exhibitivos. Esta perspectiva se aleja de la noción de patrimonialización, la cual entiende la musealización como la transformación de un lugar particular en un museo como forma de preservación (ejemplo de esto son los lugares arqueológicos). Desde un punto de vista museológico, la musealización es la intervención o extracción de un objeto de su lugar de origen para hacerlo entrar en el campo de lo museal y convertirlo así, en un "objeto de museo" o musealia. Sin embargo, más allá de esta operación de traslado de objetos, es un proceso de selección, tesaurización y presentación de éstos que pasa por conceptualizaciones con las que adquieren un estatus particular y se convierten en testimonio y representación de un momento histórico y de sus contextos (ICOM, 2010).
La musealización de la memoria es una práctica cada vez más recurrente en países del Cono Sur, dada las múltiples dictaduras militares de las décadas de los años 60, 70 y 80, las situaciones de conflictos armados, entre otros hechos, y como estrategia para revisitar el pasado. En este marco, emergen diversas investigaciones interesadas en el análisis de estas prácticas, que a pesar de ser locales mantiene un diálogo con experiencias internacionales.

Como se enfatizó más arriba, el Holocausto judío se ha convertido en tropos universal de referencia para la construcción de las memorias traumáticas. En ese sentido, la investigación de Wanda Wechsler analiza la construcción de la memoria en Argentina, llevada a cabo en la década de los noventa, como resultado de un fenómeno global de la memoria que dialoga con dicha referencia. Esta investigación analiza "Ios sucesos internacionales y nacionales que dieron lugar a la proliferación de estas prácticas memoriales que sirvieron de contexto para la creación del Museo del Holocausto en Buenos Aires" (Wechsler, 2015).

Por su parte, investigaciones realizadas en países como Brasil y Uruguay también comparten un 


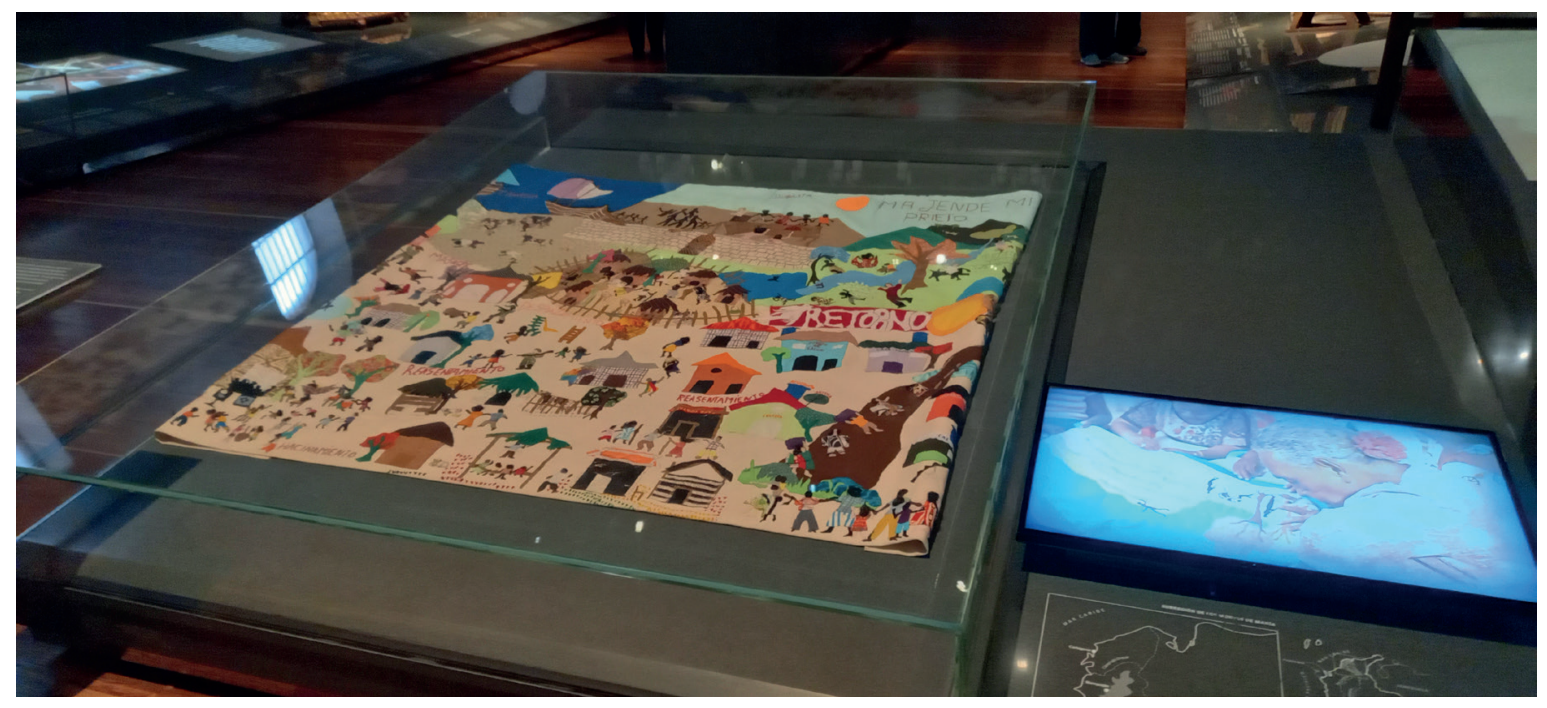

interés por revisitar sus pasados y de revisar el lugar de las políticas públicas de memoria que han propiciado la (re) construcción pública de la memoria traumática. Políticas que se materializan en espacios museales, memoriales, entre otros, donde se pone de relieve las tenciones entre intereses y juegos políticos, conflictos, ente el gobierno y la sociedad (Sosa; Mazzucchi, Ferreira, 2014).

Otras investigaciones realizadas en España y Argentina, respectivamente, tienen como objetivo poner de relieve la representación de las víctimas en procesos de musealización de la memoria, las confrontaciones y procesos sociales que genera tal representación, se preguntan por los lenguajes y sus formatos (Escribano, Gonzálvez, 2018). También se ha puesto de relieve las tensiones que atraviesa la categoría víctima, en políticas de la memoria vinculada a la construcción de sitios de memoria en Argentina, preguntándose por "¿Cómo son construidas, calificadas y presentadas las víctimas en los sitios y lugares de la memoria de la ciudad de Buenos Aires? ¿Qué identidades se ponen en juego y cómo aparecen caracterizadas en las actividades, debates, discusiones que forman parte de dichos lugares? (Messina, 2019).
Algunas otras investigaciones reflexionan sobre los sitios, espacios y marcas de la memoria en el contexto Latinoamericano, poniendo de relieve tanto las materialidades de la memoria y su transmisión como las políticas de memoria, sus dilemas, desafíos y tensiones además de los contextos históricos políticos y estatales, que con sus narrativas impactan la escena pública y política (Larralde Armas; Salvatori, \& Diz, 2018). Algunas están referidas a producciones artísticas como el cine (de ficción o documental), la plástica, o la literatura, así como el auge de los testimonios para la producción de la Memoria en Argentina con el fin de dar cuenta no solo de la represión, sino también de la reivindicación (Franco; Levín, 2007); (Fressoli, 2014).

En el contexto colombiano, la musealización de la memoria del conflicto ha sido abordada por Juan Carlos Arboleda y Milton Danilo Morales Herrera. Ellos, en su investigación, exponen los dilemas entre memoria y olvido en el contexto nacional donde prima el recuerdo de hechos violentos. Señalan cómo la administración de la memoria es un ejercicio político de ocultamiento y aluden a la musealización como relato épico que no logra dar cuenta de la magnitud del conflicto interno, poniendo en consideración el lugar del museo en la construcción de un único relato verdadero (Arboleda; Morales Herrera, 2016). Investigaciones 
como la de Julie Lavielle, centran su atención en cómo la audiencia del Museo Casa de la Memoria de Medellín, recibe los relatos museográficos sobre el conflicto armado cuando éste aún continua vigente. Su trabajo, acude a una apuesta metodológica cualitativa y cuantitativa que incluye cuestionarios y entrevistas para dar cuenta de las maneras como se configuran las relaciones entre audiencia y museo; orientadas por las relaciones personales de éstos con el conflicto, las opiniones que circulan en la sociedad sobre política, así como el rol de éstos durante la visita al museo (Lavielle, 2020).

Como vimos, las prácticas de musealización han sido principalmente abordadas para dar cuenta de los diálogos que establecen con otras formas globales de musealizar la memoria y para reflexionar sobre las políticas de memoria y las tensiones entre la población y el Estado. Con mi investigación pretendo poner en consideración la musealización y su rol con la audiencia, pues considero que, en las exhibiciones, los objetos son dispuestos en relación a cualidades y valores particulares y ésta, la audiencia, dispone su cuerpo y su mirada a la contemplación, ambos siguiendo lineamientos morales y de tradición católica. Uno de mis aportes será reflexionar sobre cómo en este proceso entra en juego la subjetividad, así como las formas del representar y del ver como posibles formas programadas y coloniales.

Es por eso que me interesa indagar por la musealización como una posible tecnología desde la cual se media la experiencia de los y las espectadoras, presuponiendo un repertorio de respuestas "normales" $y$, en consecuencia, propiciando determinadas formas de subjetivación. Así mismo, si la exhibición opera como tecnología a partir de mediaciones y negociaciones, a menudo inadvertidas, en las que los discursos -visuales o textualescontribuyen a la creación de una mirada particular, dócil pero libre, que asume su libertad e identidad en el proceso mismo de su sometimiento.

\section{Régimen visual y colonialidad}

El régimen visual o régimen escópico (siguiendo el término introducido por el historiador norteamericano Martin Jay [Jay, 2008]), se refiere a un específico modo de ver y representar en la sociedad, que tiene funciones particulares, que privilegia ciertos intereses, así como la mirada por encima de otros sentidos, dando como resultado el falogocularcentrismo (Jay, 2008). En contextos latinoamericanos, como el colombiano, se ha construido un régimen escópico y representacional ligado a prácticas y valores de tradición católica que impacta otros espectros culturales, históricos y epistémicos, que tienen su punto de partida en las formaciones del colonialismo cultural (Quijano, 2011).

De acuerdo con Quijano, la reorganización cultural realizada en la constitución de América deja una tensión continua en la subjetividad, donde el carácter del imaginario y de los modos de conocer y de producir conocimiento se vieron impactados (Quijano, 1999). Dicha reorganización cultural se manifestó en la construcción de imágenes en la colonia, las cuales operaron como discurso ideológico y buscaron el control del cuerpo vía la lectura "adecuada" de la imagen. En este mismo sentido, Jaime Borja señala que la pintura de la colonia y la representación de santos y santas fue una estrategia empleada para el control de los sentidos, particularmente el de la vista, y con ella del comportamiento de las personas (Boria, 2010); Mabel Moraña afirma que la imagen en la colonia devino en un doble movimiento, como vehículo de identidad y autoafirmación, pero también de sometimiento (Moraña, 2014). Así, la noción de arte colonial, que varios autores subsumen en la noción de barroco neogranadino, no solo debe servir para señalar un periodo del arte, que históricamente corresponde al pasado, sino como una forma de subordinación estética (Gómez, 2015, p. 37) y subjetiva que se mantiene aún vigente, porque la colonialidad estética se actualiza en las disputas por el control de la matriz colonial del poder.

Pedro Pablo Gómez señala que en América empieza la colonialidad estética bajo la forma de una teo-estética, antes de la aparición de la estética como disciplina filosófica. Dicha estética colonial es clave en la construcción colonial del ser de los otros, inventada por el colonizador (Gómez, 2015, p. 30). Determinada por políticas coloniales de la imagen, la pintura de santos, santas y escenas moralizantes sirvió para el control de los sentidos, mediante la espiritualización de los mismos, y la 
configuración de la mirada en clave religiosa. La teo-estética como proyecto cultural y al servicio de la pedagogía colonial se encaminó a la construcción visual de la virtud, del modelo del santo y la santa y al moldeamiento del comportamiento de quien los mira. La imagen colonial, por ejemplo, es capaz de ubicar al espectador(a)-creyente en el lugar del purgatorio y del dolor para enseñarle acerca de su corporeidad particular bajo la forma de un discurso estético y moral.

En esta misma sintonía, encontramos variadas producciones intelectuales centradas en el análisis en las imágenes de archivo que representan al salvaje, el caníbal, el primitivo, y demás producciones visuales como grabados desde los cuales se asentaron formas del ver occidentalizadas colonialidad del ver propuesta por Joaquín Barriendos, como un régimen heterárquico de poder, anclado a la matriz de la colonialidad (Barriendos, 2011; Rodríguez, 2017). Otras investigaciones más recientes han centrado su análisis en la colonialidad estética examinando obras de artistas colombianos que logran dar cuenta de mecanismos de control o expresiones de poder desplegadas por la institución del arte y por el Estado, los cuales limitan la posibilidad de un arte comprometido con lo social, y ponen de relieve prácticas culturales que evidencian un desprendimiento epistemológico de las artes (Peláez Ramírez, 2018).

Autores como Sergio Martínez Luna, señalan la genealogía de la visualidad entrelazada con el sostenimiento de la autoridad, el colonialismo, el totalitarismo y la violencia, siendo frecuentemente identificada más con la vigilancia, el voyerismo y el espectáculo que, como potencia epistemológica, proyecto político, ético, teórico y metodológico (Martínez Luna, 2012). Con esto, el autor nos alerta a pensar que el acto de ver es también una práctica situada en la escena del conocimiento, y nos invita a transformar sus usos frecuentemente centrados en la cosificación e instrumentalización para sostener relaciones de poder, esencializar identidades, des-politizar la diferencia; en respuesta a esto, apela a un uso epistemológico y metodológico que no sea necesariamente represor y que reconozca la autoridad al sujeto que mira.

En esa sintonía, y desde una apuesta de Estudios visuales latinoamericanos o de "estudios visuales en español" (Jiménez del Val, 2017), propiciados por la influencia de la crítica cultural (Arfuch, 2019) y por el Giro decolonial (León, 2012), encontramos investigaciones como las de Deborah Poole, quien propone una visualización de los pueblos andinos desde una perspectiva decolonial que permite otra construcción de la historia y la memoria, y otras formas de ver-leer las imágenes, que sumado a la "economía visual"; examinan sus formas de producción, circulación y consumo (Poole, 1997).

Otras apuestas como la de Sayak Valencia y Katia Sepúlveda, proponen una relectura de la noción fascinante fascismo acuñada por la crítica cultural Susan Sontag, para remplazarla por la fascinante violencia y pensar la mercantilización y el consumo de la violencia visual en el México contemporáneo. Así mismo, proponen la actualización del régimen visual, planteándolo como régimen necro-escópico de la narcocultura, atravesado por la economía y el mercado global. Esta forma de estetización de la violencia es heredada del colonialismo y del fascismo como técnica de subjetivación (Valencia y Sepúlveda, 2016).

En esta misma sintonía Marta Cabrera, explora las políticas de la imagen en las formas de la espectacularización de la guerra producida a través de la imagen y algunas tecnologías usadas en operativos militares, como Fénix y Sodoma. La autora pone de relieve el lugar de la imagen de los cuerpos expuestos como puesta en escena "ideologizada y corporalizada" (Cabrera, 2020).

Mi propuesta cruza varias de estas perspectivas aquí esbozadas, por lo cual propongo poner de relieve los lazos y vigencia de la colonialidad, presentes en las representaciones y modos de ver en procesos de musealización del conflicto armado colombiano. Estos modos de ver y de representar están ligado a valores patriarcales configurando la heteromirada (Cabrera, Segura, 2011), que da como resultado un régimen escópico colonial y patriarcal, en particular una posible mirada moral que pretendo indagar.

En mi investigación me interesa considerar cómo estas imágenes hacen parte del régimen semiótico del dolor (Vargas Martínez, 2020); me refiero a un específico modo de producción de signos sobre la violencia, de alto contenido moral, centrado en 
las representaciones de las víctimas y el dolor, que es recurrente en procesos de memorialización.

Algo interesante con las imágenes del conflicto, es que es posible rastrear conexiones entre imágenes de otros conflictos, sea de otros contextos o de otros momentos históricos, con imágenes actuales. De esa manera podemos comprender las imágenes de la violencia ligadas en el tiempo y ver cómo el régimen semiótico del dolor se filtra en nuestro imaginario.

Un aporte de mi trabajo consistirá no solo en interrogar la imagen sino el lugar de la mirada, y de quien mira, y apelar así, a lo que Nicholas Mirzoeff denominó el derecho a mirar como punto de partida para una "contrahistoria de la visualidad", basada en las formas de oposición a esa alianza entre visualidad y poder (Mirzoeff, 2003). Frente a ella, el derecho a mirar implica una mirada relacional, igualitaria y recíproca. Esto no significa renunciar en bloque al concepto de visualidad, sino hacer el esfuerzo de rearticularla con el discurso y la práctica crítica, dentro de un contexto interdisciplinar. Lo anterior en el mismo sentido de la Soberanía Visual (Rojas Sotelo, 2018), entendida como una apuesta que permite reconocer la posibilidad emancipatoria de quien mira y su lugar en la construcción de otros imaginarios, otras narrativas y otras memorias colectivas. En esta línea, las apuestas críticas de los Estudios Culturales han examinado el lugar de las audiencias como activas en la producción de sentido, al tiempo analizan la recepción, la identificación, el dilema de la interpretación, así como la interpelación, posicionando la teoría psicoanalítica (Morley, 1996).

Mi apuesta considerará la interrelación de la conmiseración de la mirada y la colonialidad del sentir, para develar los procesos de subjetivación política, absorbidos por los imperativos de una globalidad feroz, y que poco aportan a la transformación (Rivera Cusicanqui, 2018; Fassin, 2016; Taylor, 2017). Estas apuestas aportarán a la producción de conocimiento sensible al develar estas situaciones como formas movilizadas mediante políticas, y muchas veces inconscientemente performadas por los públicos.

\section{Imagen y Memoria}

Una posible articulación entre imagen y memoria es brindada por la crítica cultural argentina Leonor Arfuch, para quien, "narración e imagen se unen de manera indisociable en todo intento, y por ende en toda política de transmisión de la memoria" (Arfuch, 2012). La autora enfatiza en la dimensión icónica de la palabra que hace del relato una "pantalla proyectada", que activa (o construye) imágenes en nuestra mente. Así mismo, enfatiza en el carácter narrativo de la imagen, en tanto que ésta puede dar cuenta de una sucesión de hechos. En esta unión indisociable entre palabra-imagen, actúa un destinatario o destinataria, quien mira, pero además escucha y activa otros sentidos, y quien hace posible este movimiento entre imagen-palabra. Arfuch, propone interesantes reflexiones sobre el poder de la imagen y su impacto en la construcción de imaginarios (2012), así como el dilema de la imagen y la saturación mediática, la aceleración tecnológica y la responsabilidad de la mirada (Arfuch, 2006).

Las imágenes de violencias, particularmente las fotográficas, han sido abordadas desde análisis que abarcan su iconicidad y el reconocimiento a su capacidad de ilustrar los horrores de la guerra. La fotografía de guerra ha suscitado un interés por las relaciones entre el ver y conocer la historia e interrogarla desde la imagen (Huberman, 2004), a su vez ha impuesto históricamente a nivel global sistemas sexuales normativizados (Gutiérrez y Resende, 2018), donde, por ejemplo, el género y raza son sistemas visuales de poder y la fotografía una tecnología social a través de la cual se ha normalizado la mirada sexuada y racializada a los cuerpos (Fock, 2014). Así mismo, desde la fotografía de las víctimas se ha producido un multiculturalismo visual (Arfuch, 2008) y un modelo particular de rostricidad (Deleuze y Guattari, 1994) como forma legítima de producción de rostros de las víctimas.

En el contexto latinoamericano, algunas investigaciones reflexionan sobre los vínculos entre fotografía, memorias y violencia políica, como la represión dictatorial en países como Argentina y Chile, las imágenes del movimiento estudiantil en Brasil y las matanzas ocurridas en México. Todos estos episodios permiten indagar por el rol de las 
imágenes en contextos de violencia política en el pasado reciente (Fortuny; Gamarnik, 2019). Otras, se centran en el rescate de la memoria colectiva vía de la fotografía en exposiciones como Yuyanapaq en Perú, realizada por la Comisión de la Verdad y Reconciliación (CVR) y proponen cuestionamiento sobre sus usos, desde los cuales se sustenta una serie de verdades parciales y cambiantes sobre la violencia y se validan formas estereotipadas de percepción visual (Poole; Rojas Pérez, 2010).

En el contexto colombiano, varias investigaciones han centrado sus reflexiones en torno de la representación de las víctimas del conflicto armado desde análisis visuales de medios de comunicación hegemónicos y no hegemónicos para poner de relieve la disputa por la visibilidad de éstas y la creación de consensos sociales (Llanos; Rocha, 2018) y prensa, para dar cuenta de los llamados "campos de concentración de las FARC" y la relación visual o "reciclaje visual" que guarda con las imágenes de los campos de concentración Nazis (Bonilla Vélez, 2018) así como también para hablar de la barbarie como forma de especificidad desgarradora de la guerra y la visibilidad social, política y cultural de ésta (Bonilla Vélez, 2019). Otras, por su parte, examinan en la fotografía realizada por artistas la manera cómo opera el estereotipo y cómo éste trabaja en la construcción la víctima (como mujer anónima) la cual se relaciona con la imagen religiosa mariana y cómo pese a esto, se construye una forma consensuada de representación visual de la guerra en Colombia (Gamboa, 2017). Algunos acercamientos se dirigen hacia las exposiciones para poner de relieve la sobreexposición de sus rostros como estrategia ante prácticas de borradura (Arias, 2019). Otras, por su parte, proponen que la fotografía sigue los principios del montaje y sirve de estrategia para contar las historias del horror del conflicto armado colombiano (CogolloOspina, 2017). Otras ponen de relieve cómo algunas imágenes "se encuentran muy distantes de la continuidad simple de la percepción cotidiana", y dan cuenta de sobrevivencias que coexisten en territorios devastados (Méndez, 2016) y establecen relaciones entre la imagen, el imaginario y la memoria colectiva, indagan el cartel de denuncia y cómo los videos se establecen como un insumo fundamental para dar cuenta de una representación social de nuestro pasado político (Jiménez,

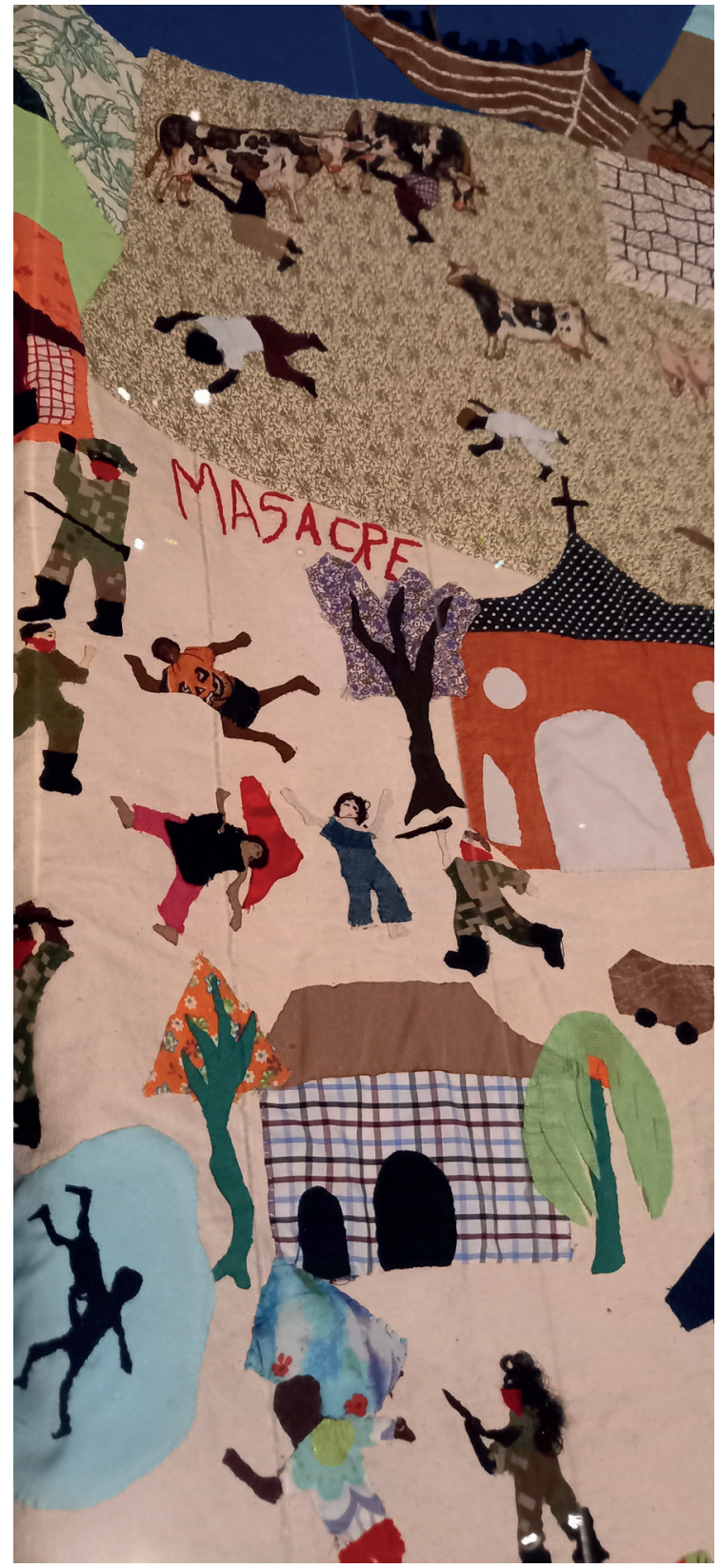

Imagen 5. Mantos de Mampujan, realizados por mujeres tejedoras de Mampuian. Sala Memoria y Nación, Museo Nacional de Colombia. Archivo personal.

2012). Otras investigaciones se centran en el mercado de las artes y la representación de la violencia y el trauma, examinado algunas obras realizadas por artistas como Doris Salcedo y Fernando Botero, y cómo en sus obras, en sus procesos de 
producción y sus modos de exhibición se articulan memoria e identidad nacional (Cabrera, 2007).

Investigadores como Alex Schlenker (2012, 2015), desde una perspectiva decolonial, proponen la "acción teórical" como una forma de integrar teoría y práctica en torno de la visualidad y como práctica para descolonizar la vida, mediante la triangulación memoria-imagen-relato, así como metodologías combinadas. O Marta Cabrera y Juan Carlos Segura, quienes plantean que memoria y visualidad permiten actos de reinterpretación, donde convergen, estética, política y cultura, y que la crítica de lo visual es una forma de intervención (Cabrera, Segura, 2010).

En esa sintonía, la imagen y la memoria son abordas por artistas y realizadores audiovisuales, desde el video ensayo como una forma de investigación-creación, al alrededor de la imagen generada por la Catástrofe como fenómeno natural o accionado por sujetos y de la mirada y el impacto emocional-visual que esta genera (Salamanca, 2017). El ensayo audiovisual permite la exploración crítica de la representación de la guerra en Colombia que ha devenido en fenómeno mediático (al ser construido en imagen) y como narrativa fragmentada y polarizada (al reproducir una determinada ideología neoliberal), apelando al enrarecimiento de las imágenes y hacernos sospechar de éstas, haciendo uso de aquellas imágenes residuales, dejada de lado en los noticieros, en el uso de planos y ángulos que producen distanciamientos con la imagen (Campo, 2011).

Algunas realizaciones dirigen su mirada al registro del drama acaecido tras el fenómeno de la desaparición forzada y el impacto de éste sobre las familias. Los relatos visuales (fotografías en blanco y negro y mayormente a color) son compuestos por objetos personales y prendas de vestir encontradas y pertenecientes a personas desaparecidas (Botero, 2010). En contravía, otros realizadores brindan un registro visual opuesto a la imagen y al discurso sobre las víctimas y victimarios construido por los medios de comunicación y el propio Estado y proponen escenas de la vida cotidiana de las FARC, como fiestas, bailes, comidas realizadas en zona rural, la montaña o el monte, las relaciones familiares y afectos invisibilizados en los discursos oficiales (Ríos, 2019).

\section{Subjetivación y afectos}

Más recientemente, el abordaje de los procesos de subjetivación y los afectos han cobrado relevancia en la academia. Subjetivación y afectos como potencia para indagar los procesos a través de los cuales nos construimos como sujetos (Foucault, 1996) y manifestamos nuestra subjetividad. La noción de subjetivación problematiza la noción estabilizada de identidad. De su lado, el Giro afectivo "se ha instalado como enfoque de investigación en prácticas inter- $y$ transdisciplinarias de teoría crítica y estudios culturales en la academia anglosajona (Del Sarto, 2012) y más recientemente se ha incorporado en los estudios realizados en América Latina como prisma interpretativo de la cultura y la sociedad. Pero también "somos protagonistas de la exhibición y tematización de la intimidad y del sentir individual en diferentes ámbitos de la vida pública", movilizado por los medios de comunicación y las redes sociales que permean el terreno de la política (Abramowski; Canevaro, 2017).

Los estudios sobre subjetivación y afectos, dialogan críticamente con las teorías que los recogen y al tiempo se ponen en relación con contextos y temas como la globalización, la relación con la experiencia y los cuerpos (Del Sarto, 2012). Algunas investigaciones centran el efecto de las imágenes en la corporalidad, la relación con los sujetos; donde el cuerpo es el lugar de las experiencias perceptivas y de producción de sentido (De Angelo, 2010). Así como la narrativa, el cine, la poesía, en su relación con el discurso político y las dimensiones del consumo. "Se estudia así el afecto como vehículo epistémico alternativo a la racionalidad instrumental, como rasgo distintivo de la modernidad y como desafío y suplemento de la productividad capitalista" (Moraña, 2012).

Desde algunas apuestas feministas, se examina el carácter público de las emociones y el carácter emotivo de las audiencias. Qué hacen las emociones, es una de las principales preguntas que orienta esta perspectiva y que al tiempo busca complejizar su funcionamiento. Para ello, autoras como Sara Ahmed, ha planteado la noción Economía política de las emociones, para dar cuenta de las condiciones de producción, los 
circuitos de distribución y las situaciones para su recepción (Ahmed, 2019). Esta apuesta pone en consideración las maneras como son movilizadas por el estado, el gobierno, las campañas de comunicación y distintas instituciones, formas del sentir como técnicas para vivir, que impactan los cuerpos y la esfera pública. Justo aquí el feminismo interpela esas formas "adecuadas" en un horizonte normativo que se asume como necesario.

En el contexto Latinoamericano, la memoria y su relación con los afectos se introducen como una vía para la reflexión sobre los usos del pasado, los sentidos y significados de las memorias "para los sujetos cuyas experiencias del pasado fueron negadas por los Estados Nación y los imaginarios dominantes" (Ramos; Bompadre, 2018). Así como el quiebre social y subjetivo dejados por las dictaduras en países como Argentina o Chile. En particular algunas investigaciones examinan la identidad de género y su relación con la militancia política, para identificar la autoridad patriarcal legitimada. En el caso argentino los efectos personales y familiares de la militancia en las filas montoneras (el ala más radical del peronismo) y en el chileno en el MIR (Movimiento de Izquierda Revolucionario) y el partido comunista, revelan los costos que la causa política y la clandestinidad tuvieron para las mujeres como esposas e hijas (Llanos, 2012). En otros casos, se estudian los procesos de memoria vinculada a la violencia política en su relación con la dimensión afectiva en el contexto argentino (Saporosi, 2018). Se ha estudiado cómo el afecto influye en la construcción de significados compartidos, en el marco de los actos de protesta colectiva, "producto de la comunión entre individuos" (Rodríguez Hernández; Juárez Lugo; Ponce de León, 2011).

En el contexto de las exhibiciones, el estudio de los afectos se empieza a introducir para examinar las relaciones participativas y democráticas de los museos de memoria con las comunidades. Se examinan las relaciones entre la institución, la museografía y los objetos de la colección. Se propone la noción testigo emocional "como una capa fundamental que se entrelaza en los mecanismos narrativos que despliega el museo en sus exhibiciones" (Ordoñez-Castillo, 2018). Otras investigaciones examinan cómo en espacios de memoria de la violencia política, como es el caso de Argentina, la memoria opera como "un proceso articulador entre pasado-presente-futuro, lo constitutivo de dicha conexión es la violencia política del Estado, la amenaza que esta constituye para quienes llevan a cabo acciones políticas que cuestionan o tensionan el orden social y el miedo que ello produce". A partir de examinar las experiencias de las personan que visitan los lugares de memoria, se determina cómo el miedo trabaja en la construcción de tres generaciones; generación traumatizada, la generación heredera del miedo y la generación sin miedo. El miedo es allí propuesto como motor de acción colectiva a través del cual se construyen recuerdos, posibilidades y sujetos (Piper Shafir, 2015). Un aporte de esta investigación-creación al estudio de la memoria del conflicto colombiano, será examinar el carácter público de las emociones y develarlas como tecnologías o agendas de control afectivo, las cuales prolongan las distintas dimensiones de la colonialidad vía la visualidad.

\section{A manera de cierre}

Hacer una entrada al estudio de la memoria del conflicto desde la investigación-creación, desde un abordaje contextual y la intervención transdisciplinar (entre estudios culturales, y estudios visuales, con enfoques decoloniales y feministas) es potente, pues este enfoque permitirá poner en consideración cómo lo visual es atravesado por lo social, aportando al entendimiento de cómo se normalizan determinadas construcciones culturales, para intervenirlas. Propongo, en términos de Stuart Hall una "lucha con los ángeles" (Hall, 1992), un forcejeo con la teoría, desde la fantasía e imaginación epistemológica, para construir y articular nuevas formas de comprender e intervenir el mundo.

Poner de relieve la musealización de la memoria del conflicto, como una serie de prácticas selectivas que centran la presencia de lo visual, aportará un nuevo enfoque de estudio hacia los efectos y afectos que producen y movilizan dichas prácticas.

En consecuencia, esta apuesta reclama estrategias de producción de conocimiento desde lo local, así como abordajes inter y transdisciplinarios, de carácter fronterizo y en construcción permanente (Gómez, 2018). Es por ello que los estudios 
artísticos devienen para mí en el lugar idóneo para producción de conocimientos sensibles y para el despliegue de apuestas críticas. Intrínseca a los estudios artísticos, la perspectiva decolonial permitirá profundizar sobre las maneras como operan los regímenes visuales, que impactan el sentir y el creer, con sus efectos de subjetivación que emergen como parte de agendas de producción hegemónica de sentidos y afectos. Una agenda que opera como mecanismo de control. Así mismo, la apuesta feminista como enfoque puede aportar al estudio de las imbricaciones de las clasificaciones de género, raza, etnia, como procesos coloniales vigentes en las exhibiciones y en sus relatos. También permitirá problematizar el régimen de producción de lo sensible que ahí se pone en marcha; es decir, el lugar y funcionamiento de las emociones y su relación con la memoria, y las posibles maneras como este régimen deviene en una política estatal de administración de la memoria y el olvido, que opera a nivel local y global.

\section{Con la relectura de las exhibiciones en cuestión} como tecnología del género siguiendo la apuesta de la teórica feminista Teresa De Lauretis (1989), -quien retoma la noción de tecnología de Foucault-, y para quien el género debe entenderse como un aparato semiótico, un sistema de representación, que asigna significado (identidad, valor, prestigio, ubicación en una jerarquía) y opera mediante la ideología y la interpelación. En las exhibiciones hay una marcada forma de representación de mujeres y minorías como víctimas. En este marco, resulta interesante aventurarse a ampliar y situar dicha tecnología a nuestro contexto, atravesada por la raza, la etnia y la clase que reproducen y prolongan jerarquías coloniales de poder. Con esta apuesta propongo poner de relieve las estructuras mediante las cuáles opera y, de paso, aportar a la comprensión de las prácticas artísticas y de la memoria más allá del estudio de la imagen como un entramado de signos y códigos.

El acercamiento desde la investigación-creación involucra necesariamente una reflexión sobre aquello que estructura y posibilita o se opone a su realización, lo que media, afecta y moviliza. En este sentido, más que métodos de visión (es decir, técnicas de lectura de las imágenes) propongo una reflexión sensible sobre las políticas coloniales de visualidad vigentes, la desnaturalización de las estructuras que determinan el campo visual, y que de paso complejicen las formas del ver y el ser.

Esta investigación creación contribuirá al posicionamiento de los estudios artísticos mediante la exploración y producción de conocimiento sensible en torno a las maneras como se exhiben las memorias del conflicto interno en Colombia, como vía para develar las tecnologías y agendas de control, que prolongan las distintas dimensiones de la colonialidad. Contribuirá a re-pensar el buen vivir en tanto le apuesta por la construcción de posturas críticas frente a las formas canónicas y homogéneas del hacer en el campo del arte que proyecten nuevas posibilidades. Si bien hay una insistencia en la construcción de memorias plurales para contrarrestar la hegemonía del recuerdo único del pasado, es necesario que la pluralidad no solo esté dada en una variedad de imágenes, voces o relatos que se exhiben, es necesario que la pluralidad se de en la exploración de variadas formas del mostrarlas, exhibirlas y contarlas. Este es precisamente, uno de los principales resultados esperados, apelar a nuevas formulaciones del mostrar que no homogenicen los objetos de la memoria y aplanen sus lecturas. Así mismo un resultado esperado es que desde estas apuestas se posibiliten otras formas del ver y otras experiencias de la mirada que superen la relación ver-conocer y que propongan otras formas de subjetivación política que no se enmarquen necesariamente en la conmiseración, sino que activen otras formas entre el ver-asumirse y el experienciarse en y con el mundo.

\section{Referencias}

\begin{abstract}
Abramowski, A, Canevaro, S. (2017). Pensar los afectos. Aproximaciones desde las ciencias sociales y las humanidades. Buenos Aires: Universidad Nacional de General Sarmiento.
\end{abstract}

Ahmed, S. (2019). La política cultural de las emociones. Buenos Aires: Caja Negra.

Arboleda, J. C., Morales Herrera, M. D. (2016).

"Musealización de la memoria y conflicto armado". En: Conflicto armado, justicia y memoria en Colombia. Tomo 3. Narrativas de la memoria. Medellín: UPB. 
Arfuch, L. (2012). Memoria e Imagen. Revista Educación y Realidad, Porto Alegre, 37(2), pp. 399-408.

Arias Herrera, J. C. (2019). La borradura del rostro: prácticas artísticas y el problema de la visibilidad de las víctimas. Palabra Clave, 22(2). Bogotá, Colombia: Pontificia Universidad Javeriana.

Barriendos, J. (2011). La colonialidad del ver. hacia un nuevo diálogo visual interepistémico. Nómadas (Col), 35(octubre), pp. 13-29. Bogotá, Colombia: Universidad Central.

Borja, J. (2002). "El discurso visual del cuerpo barroco neogranadino". Universidad Nacional de Colombia, Instituto colombiano para el desarrollo de la Ciencia y la Tecnología Francisco José de Caldas. (pp. 168 - 181).

Bonilla Vélez, J. I. (2018). La barbarie que no vimos. Fotografía y memoria en Colombia. Colección Académica. Colombia: Escuela de Humanidades. Universidad EAFIT.

Cabrera, M. (2007). Representing Violence in Colombia: Visual Arts, Memory and Counter-Memory. Brújula, 6(1).

. (2020). "Espectáculos de Estado: visibilizando al enemigo en la seguridad democrática". Violencia, memoria y sociedad: debates y agendas en la Colombia actual. Bogotá, Colombia: Universidad Santo Tomás.

Cabrera, M., Segura, J. C. (2009). "Del ver la memoria”. En: Estudios Visuales y Estudios Culturales: nuevas apuestas de investigación crítica. Disponible en: «https://vsip.info/ qdownload/estudios-visuales-y-estudios-culturales-ineditos-pdf-free.html»

Coro Rubio, P. (2016). Los rostros de la memoria. El fenómeno memorialista en el mundo actual y sus usos políticos. Localización: Historia y política: Ideas, procesos y movimientos sociales, 35, pp. 343-368. ISSN 1575-0361.

Cogollo-Ospina, S. (2017). La fotografía como estrategia para contar historias del horror del conflicto colombiano. Calle14: revista de investigación en el campo del arte, 12(21), pp. 1-16. Bogotá, Colombia: Universidad Distrital Francisco José de Caldas.

D’ Angelo, A. (2014). La experiencia de la corporalidad en imágenes. Percepción del mundo, producción de sentidos y subjetividad. Tabula Rasa, 13(julio-diciembre),pp. 235-251.
De Lauretis, T. (1989). "La tecnología del género". En: Technologies of Gender. Essays on Theory, Film and Fiction, London: Macmillan Press.

Deleuze, G., Guattari, F. (1994). Mil mesetas: capitalismo y esquizofrenia. Valencia: Pretextos.

Escribano, Gonzálvez, E. (2018). Musealizar la memoria de las víctimas, Revista Historia Autónoma, 12, pp. 261-278.

Fortuny, N., Gamarnik C. (2019). “Fotografía, violencia política y memorias en América Latina". (Dossier). Clepsidra. Revista Interdisciplinaria de Estudios sobre Memoria, 6(11, marzo).

Franco, M., Levín, F. (2007). "El pasado cercano en clave historiográfica". (Capítulo)En: Franco, M. y Levín, F. (Comp.). Historia reciente. Perspectivas y desafíos para un campo en construcción. Buenos Aires: Paidós.

Fressoli, M. G. (2014). Formaciones de memoria en disputa en Argentina, desde la transición democrática hasta hoy, $8(1)$.

Fock, S. (2014). Cuerpos, miradas y memorias fotográficas. Una (de)construcción de género y raza. Tesis de Maestría Erasmus Mundus en estudios de las mujeres y de género. Granada, España.

García, M. (2013). Operación massmediática: re-elaboración de la memoria pública y conformación del archivo contemporáneo. De prácticas y discursos, cuadernos de ciencias. Sociales, 2(2).

Gómez, P. P. (2018). Lugares de encuentro y colaboración entre los estudios culturales y los estudios artísticos. en P. P. Gómez (Ed.), Aprender, crear, sanar: estudios artísticos en perspectiva decolonial (pp. 7-13; 71-102). Bogotá: Universidad Distrital Francisco José de Caldas.

(2015). Estéticas Fronterizas: diferencia colonial y opción estética decolonial. Bogotá: Universidad Distrital FJDC / Universidad Andina Simón Bolívar. (pp. 1-93).

(2016). HD: Haceres decoloniales: prácticas liberadoras del estar el sentir y el pensar. Bogotá: Universidad Distrital Francisco José de Caldas.

Guasch, A. M. (2014). La Memoria del otro en la era de lo Global. Revista de Estudios Globales y Arte Contemporáneo, 1. 
(2011). Cartografías de lo Global: Memorias y

Lugares. En: Arte y Sociedade, (Actas de la conferencia). Portugal: Universidad de Lisboa.

Gutiérrez, C., Resende, B. (2019). La violencia del ojo: cuerpo, fotografía y literatura. Revista Graphos, 20(1) p. 25.

Huberman, D. (2004). Imágenes pese a todo, memoria visual del Holocausto. (pp. 3 - 79). España: Paidós.

Hyussen, A. (2002). En busca del futuro perdido. Cultura y memoria en tiempos de globalización. México: Fondo de Cultura Económica.

Jelin, E. (2001). Los trabajos de la memoria. Madrid: Siglo $\mathrm{XXI}$.

Jiménez del Val, N. (2017). Los estudios Visuales en español. El Ornitorrinco Tachado. Revista de artes visuales, [S.I.](06), pp. 9-22.

Larralde Armas, F., Salvatori, S., Diz, M. (2018). Introducción al dossier "Espacios de memoria en Latinoamérica: conflictos, dilemas y desafíos en tiempo presente". Aletheia, $8(16)$.

Lavielle, J. (2020). Musealizar el pasado y el presente de la violencia. Un estudio de las percepciones de los visitantes del Museo Casa de la Memoria de Medellín. Desafios, 32(2), pp. 1-39.

León, C. (2012). Imagen, medios y telecolonialidad: hacia una crítica decolonial de los estudios visuales. Aisthesis, 51, p. 109-123. Instituto de Estética - Pontificia Universidad Católica de Chile.

Martínez, F. (2013). Las prácticas artísticas en la construcción de memoria sobre la violencia y el conflicto. Eleuthera, 9(2), pp. 39-58. Pereira, Colombia.

Llanos, G.M.G., Rocha, S.M. (2018). Visualidad de las víctimas del conflicto armado colombiano: palabra y memoria en contravía.TV. Revista Extraprensa, 12(1), pp. 152-174.

Llanos, B. (2012). Memoria, afectos y género en documentales argentinos y chilenos. Revista de Historia, Instituto de Historia de Nicaragua y Centroamérica-ihnca- 27(enero-junio), Disponible en: «http://ihncahis.uca.edu.ni/revistas/ index.php/historia/article/view/114/102»
Mairesse, F. (Et. Al). (2010). Conceptos Claves de Museología. París: ICOM.

Martínez Luna, S. (2012). La visualidad en cuestión y el derecho a mirar. Revista Chilena de Antropología Visual, 19(julio), pp. $20-36$.

Méndez, R. (2016). Enero 17 del 2003. Estudios Artísticos: revista de investigación creadora, 1(1). pp.141-154.

Mignolo, W. (2015). La opción decolonial. En: Trayectorias de re-existencia: ensayos en torno a la colonialidad/decolonialidad del saber, el sentir y el creer (P. P. Gómez Ed.), (pp. 51-70). Bogotá: Universidad Distrital.

Messina, L. S. (2019). Lugares y políticas de la memoria. Notas teórico-metodológicas a partir de la experiencia argentina. Kamchatka. Revista de análisis cultural, (13 de junio), pp. 59-77.

Moraña, M. (2014). "La indecencia de las imágenes, América y sus rostros occidentales". En: Inscripciones críticas, ensayos sobre cultura latinoamericana, (pp. 105 - 125). Santiago de Chile: Editorial Cuarto Propio.

Moraña, M., Sánchez Prado, I. (Eds.). (2012). El lenguaje de las emociones: afecto y cultura en América Latina. Madrid, España: Iberoamericana Vervuert.

Morley, D. (1996). Televisión, audiencias y estudios culturales. Buenos Aires: Amorrortu Editores.

Ordoñez-Castillo, D. (2018). Del testigo virtual al testigo emocional: lugares, tecnologías y afectos en el Museo Casa de la Memoria de Medellín. Tesis de Maestría en Estudios Sociales de la ciencia. Universidad Nacional. Biblioteca Digital.

Panozzo-Zenere, A., Olivari, M.C. (2020). La exhibición de arte en la contemporaneidad. Lecturas críticas entre los giros temáticos y el esquema constelar. Arte, Individuo y Sociedad, 32(4), pp. 903-916.

Peláez Ramírez, Á. M. (2018). Régimen visual y colonialidad estética: tres diálogos con la historia del arte colombiano. Tesis de Maestría. Maestría en Estudios de la Cultura. Universidad Andina Simón Bolívar, Sede Ecuador.

Piper Shafir, I. (2015). Violencia política, miedo y amenaza en lugares de memoria. Athenea Digital. Revista de pensamiento e investigación social, 15(4). 
Poole, D., Rojas Pérez, I. (2010). Memorias de la reconciliación: fotografía y memoria en el Perú de la posguerra.

e-misférica, 7.2. Disponible en: «https://hemi.nyu.edu/hemi/ es/e-misferica-72/poolerojas»

Quijano, A. (2000). Colonialidad del poder y clasificación social. Journal of World systems research, VI(2), pp. 342-386.

Ramos, A. M., Bompadre, J. M. (2018). Procesos de Memoria: Introducción. Punto CuNorte, 7, pp. 7-26. México: Universidad de Guadalajara.

Richard, N. (2018). Abismos temporales: feminismo, estéticas travestis y teoría queer. Santiago de Chile: Ediciones Metales pesados.

Rodríguez, V. M. (2017 [2009]). "La colonialidad del ver: Estudios Culturales/ visuales/ artísticos". En: Bustos, Marta (Ed.). Diálogos a propósito de los estudios artísticos. Bogotá: Universidad Distrital Francisco José de Caldas- ASAB.

Rodríguez Hernández, G., Juárez Lugo, C. S., Ponce de León, M. Del C. (2011). La culturalización de los afectos: Emociones y sentimientos que dan significado a los actos de protesta colectiva. Revista Interamericana de Psicología/Interamerican Journal of Psychology, 45(2), pp. 193-202.

Rojas-Sotelo, M. (2016-1017) "Soberanía visual en Abya Yala". Ensayos sobre arte contemporáneo en Colombia. Premio Nacional de Crítica, (13), p.p. 5-15. Bogotá: Ministerio de Cultura.

Saporosi, L. (2018). Los afectos y la memoria. Anclajes, 22(2), (mayo-agosto), pp. 97-114.

Sosa, A. M., Mazzucchi Ferreira, L. (2014). Memoria musealizada: un estudio sobre los procesos de patrimonialización de memorias traumáticas en Uruguay y Brasil. Revista Eletrônica do Programa de Pós-Graduação em Museologia e Patrimônio, 7(1), PPG-PMUS UniRio. MAST.

Schlenker, A. (2012). "Imagen, Memoria, Modernidad: Perspectivas otras para el abordaje de la representación visual". En: Mignolo, Walter y Gómez, Pedro Pablo, (Eds.). Estéticas y opción decolonial, (pp. 162, 208). Bogotá, Colombia: Universidad Distrital Francisco José de Caldas.
(2015). Investigar-crear desde la visualidad: los secuædros del viernes santo de Alangasí. Estudios Artísticos: revista de investigación creadora, 1(1), pp. 120141. https://doi.org/10.14483/25009311.10251

Valencia, S., Sepúlveda, K. (2016). Del fascinante fascismo a la fascinante violencia: Psico/bio/necro/política y mercado gore». Mitologías hoy, (14), pp. 75-91.

Vargas Martínez, S. (2020). "Otras imágenes del conflicto. Visualidad en procesos de construcción de la memoria en Colombia". (Ponencia). Primer Coloquio Nacional Visualidad, formación y violencia política: ente lo visible y los invisible. (Del 3 al 5 de noviembre). Bogota, Colombia: Universidad Pedagógica Nacional.

Vargas Martínez, S. (2020). Venga y mire. Estudios Artísticos: revista de investigación creadora, 6(9), pp. 180-194.

Vezzetti, H. M. (2015). Historia y memoria; Asociación Argentina para el Progreso de las Ciencias. Ciencia e Investigación, 65(4), pp. 23-27.

Wechsler, W. (2015). La construcción y musealización de la memoria del Holocausto en la Argentina reciente. Aletheia, $5(10)$. 